\title{
FAKTOR - FAKTOR YANG MEMPENGARUHI UNDERPRICING IPO DI BURSA EFEK INDONESIA \\ PERIODE 2008 - 2013
}

\author{
Diah Dewi Permanisuci \\ Fakultas Ekonomi Universitas Sarjanawiyata Tamansiswa Yogyakarta \\ raden_wiwig@yahoo.com
}

\begin{abstract}
ABSTRACK
Abstrak : Penelitian ini bertujuan untuk memperoleh bukti empiris apakah variabel-variabel independen dalam penelitian ini, yaitu financal leverage, reputasi auditor, return on assets, reputasi underwriter, ukuran perusahaan, umur perusahaan, berpengaruh terhadap tingkat underpricing perusahaan yang terdaftar di Bursa Efek Indonesia periode 2008-2012. Penelitian ini mengguankan data dari seluruh perusahaan yang terdaftar di Bursa Efek Indonesia periode 2008-2012. Sampel yang diolah dalam penelitian ini sebanyak 94 perusahaan yang melakukan IPO. Setelak dilakukan seleksi sampel ditetapkan sebanyak 60 perusahaan yang dijadikan sampel penelitian. Hasil penelitian ini menunjukkan terjadi underpricing dalam penawaran saham perdana. Terdapat pengaruh variable reputasi Auditor, ukuran perusahaan, umur perusahaan, dengan tingkat underpricing yang listing di Bursa Efek Indonesia. Tidak ada pengaruh financial leverage, reputasi underwriter, return on asset, dengan tingkat underpicing yang listing di Bursa Efek Indonesiaassets, financal leverage, tingkat underpricing

Kata kunci: reputasi underwriter, reputasi auditor, ukuran perusahaan, umur perusahaan, return on Abstrack: This research has objective to empirical evidence that independent variables in this research ex financial leverage, reputastion auditor, return on assets, reputation underwriter, company size, firm age can be effect to underpricing companies listed in Indonesia Stock Exchange periods 2008-2012. This research uses data from all companies that listed in Indonesia stock Exchange periods 2008 - 2012. Samples are used as sixthy companies. This research show the occurrence of underpricing in initial public offering. There is variable effect auditor, company size, firm age, eith the level of underpricing that listed in Indonesia stock exchange. There is nothing influence financial leverage, reputation underwriter, return on asset with the level of underpriccing that listed in Indonesia stock exchange
\end{abstract}

Keywords:.reputation underwriter, reputation auditor, company size, firm age, return on assets, financial leverage, levels of underpricing.

\section{PENDAHULUAN}

Ketika perusahaan pertama kali melakukan penawaran sahamnya ke pasar modal, masalah pelik yang dihadapi adalah penentuan harga di pasar perdana tersebut. Di satu pihak pemegang saham lama tidak ingin menawarkan saham baru dengan harga terlalu murah (atau mengalami terlalu banyak underpricing) kepada investor baru, tetapi di sisi lain, investor baru menginginkan untuk memperoleh capital gains dari pembelian saham di pasar perdana tersebut. Karena itu seringkali pada pasar perdana atau
IPO (Initial Public Offering) dijumpai phenomena underpricing.

Dalam melakukan IPO perusahaan biasanya menggunakan underwriter (penjamin emisi) sebagai perantara dan pemberi saran, selain itu juga berfungsi sebagai pembeli saham dan sebagai pemasar saham ke investor di pasar sekunder. Semakin besar informasi asimetri yang dihadapi oleh para calon investor semakin besar pula mereka akan mempenalty penawaran harga di pasar perdana yang akan memaksa penjamin emisi menawarkan saham tersebut dengan underpriced. Disamping itu apabila 
penjamin emisi memberikan jaminan full commitment, maka jaminan tersebut juga akan memperkuat kecenderungan untuk melakukan underpricing

Laporan keuangan merupakan salah satu sumber informasi yang digunakan oleh investor potensial dan underwriter untuk menilai perusahaan yang akan go public. Agar laporan keuangan dapat lebih dipercaya, maka laporan keuangan harus diaudit. Laporan keuangan yang telah diaudit akan memberikan tingkat kepercayaan yang lebih besar kepada pemakainya.

Penelitian ini bertujuan untuk mengetahui pengaruh reputasi auditor, reputasi underwriter, umur perusahaan, return on assets, financial leverage, dan ukuran perusahaan terhadap initial return saham saat penawaran perdana

\section{RUMUSAN MASALAH}

1. Apakah berpengaruh underpricing saham?

2. Apakah Reputasi Auditor berpengaruh terhadap tingkat underpricing?

3. Apakah Return On Asset berpengaruh terhadap tingkat underpricing?

4. Apakah Reputasi Underwritter berpengaruh terhadap tingkat underpricing?

5. Apakah Ukuran Perusahaan berpengaruh terhadap tingkat underpricing?

6. Apakah Umur Perusahaan berpengaruh terhadap tingkat underpricing?

7. Apakah Financial Leverage, Reputasi Auditor, Return On Asset, Reputasi Underwritter, Ukuran perusahaan dan Umur Perusahaan secara bersama-sama berpengaruh terhadap tingkat Underpricing?

\section{TUJUAN PENELITIAN}

1. Financial Leverage berpengaruh terhadap tingkat underpricing

2. Reputasi Auditor berpengaruh terhadap tingkat underpricing

3. Return On Asset berpengaruh terhadap tingkat underpricing
4. Reputasi Underwritter berpengaruh terhadap tingkat underpricing

5. Ukuran Perusahaan berpengaruh terhadap tingkat underpricing

6. Umur Perusahaan berpengaruh terhadap tingkat underpricing

7. Financial Leverage, Reputasi Auditor, Return On Asset, Reputasi Underwritter, Ukuran perusahaan dan Umur Perusahaan secara bersama-sama berpengaruh terhadap tingkat Underpricing

\section{MODEL PENELITIAN}

Adapun model penelitian yang menghubungkan variabel-variabel independen dengan variabel dependen adalah:

(X) Variabel Dependen (Y)

$$
\text { Variabel Independen }
$$

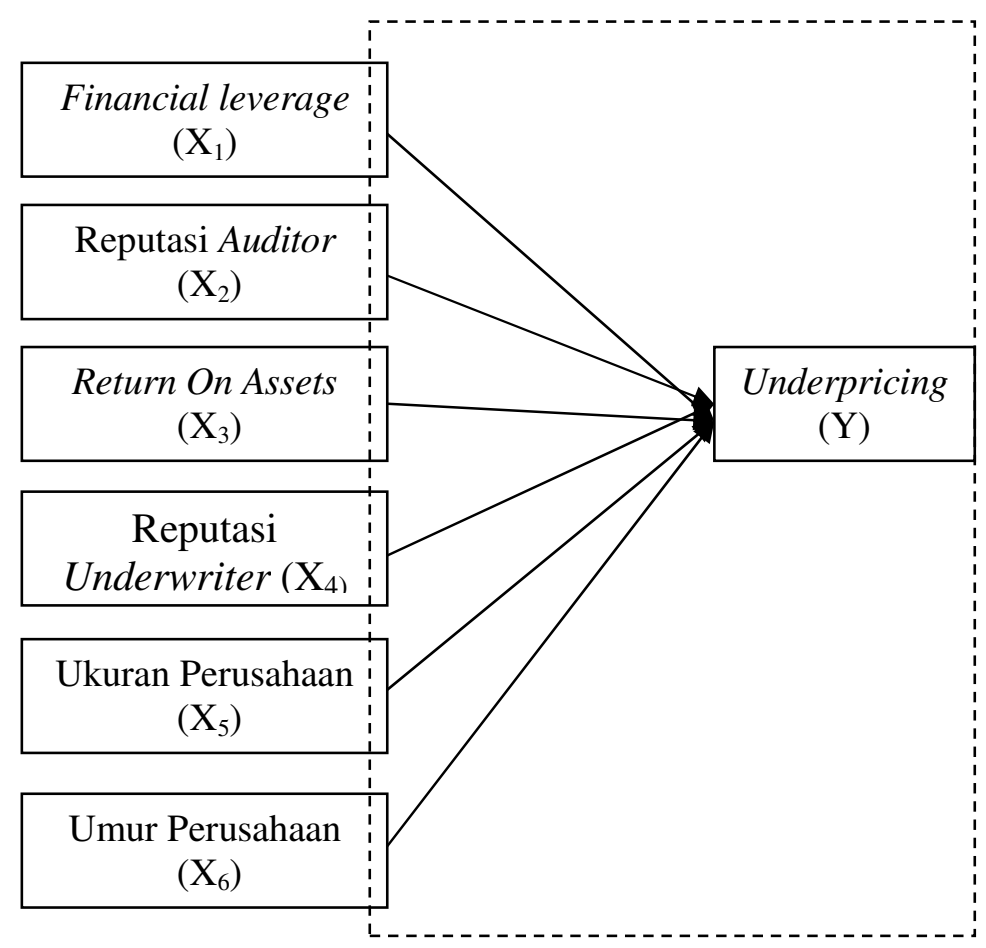

\section{METODOLOGI PENELITIAN}

Variabel Independen dalam penelitian ini adalah Financial Leverage, Reputasi auditor, ROA, Reputasi Underwriter, Ukuran Perusahaan, Umur Peruahaan. Sedangkan variable Dependen dalam penelitian inin adalah Underpricing. 
Berikut ini dijelaskan mengenai identifikasi dari variable-variabel yang digunakan dalam penelitian ini:

1. Financial laverage

Multiplier effectnya adalah Degree of Financial Leverage (DFL) yaitu persentase perubahan laba per lembar saham (EPS) dibagi dengan persentase perubahan pada laba sebelum bunga dan pajak (EBIT) (Wirawanyasa, 2009:14)

$$
\mathrm{DFL}=\frac{\text { Persentase Perubahan dalam EPS }}{\text { Persentase Perubahan dalam EBIT }}
$$

2. Reputasi Auitor

Penentuan reputasi auditor menggunakan variabel dummy. Asumsinya bila emiten menggunakan auditor yang termasuk dalam kategori big four diberi skala 1 dan bila emiten tidak menggunakan auditor yang termasuk dalam kategori big four diberi skala 0.

\section{Return On Asset}

Return On Assets (ROA) menggambarkan sejauh mana kemampuan asset-asset yang dimiliki perusahaan dapat menghasilkan laba (Jogiyanto, 2008:240)

\section{Reputasi Underwriter}

Pengukuran reputasi underwriter menggunakan metode pengukuran yang dilakukan oleh Suyatmin dan Sujadi (2007) dengan menggunakan total nilai penjaminan yang dilakukan oleh underwriter. Semakin besar nilai penjaminan yang dilakukan oleh underwriter menunjukan bahwa underwriter memiliki reputasi yang baik. Setelah diukur akan dipilih lima underwriter dengan total nilai penjaminan yang terbesar dan akan diberi skala 1, selain itu diberi skala 0

5. Ukuran Perusahaan

Variabel ini diukur dari natural log total asset perusahaan. Variabel size diperoleh dalam summary of financial statement. Secara matematis variabel size di rumuskan sebagau berikut:

$$
\text { Size }=\text { Ln Total Assets }
$$

6. Umur Perusahaan

Variabel ini dihitung mulai perusahaan didirikan berdasarkan akte pendirian sampai perusahaan melakukan IPO di Bursa Efek Indonesia

\section{Underpricing}

Variabel dependen dalam penelitian ini adalah Underpricing saham yang dikur dengan menggunakan Initial Return. Initial return adalah keuntungan yang diperoleh pemegang saham karena perbedaan harga saham yang dibeli dipasar perdana saat IPO dangan harga saham yang jual pada hari pertama dipasar sekunder.

$$
\mathrm{IR}=\frac{\text { Clossing Price }- \text { Offering Price }}{\text { Offering Price }} \times 100 \%
$$

\section{JENIS DATA DAN SUMBER DATA}

Populasi : seluruh perusahaan yang melakukan IPO yang terdaftar di Bursa Efek Indonesia.

Sampel : Seluruh perusahaan yang melakukan IPO dan mengalami Undrpricing pada saat IPO yang terdaftar di Bursa Efek Indonesia periode 2008-012.

\section{METODE PENGUMPULAN DATA}

Jenis data yang digunakan dalam penelitian ini adalah data kuantitatif yaitu nilai data yang dinyatakan dalam skala numerik. Data dalam penelitian ini merupakan data sekunder yaitu data yang diperoleh dari terbitan atau laporan suatu lembaga (Sugiyono, 2008:10).

\section{ALAT ANALISA}

1. Analisis Regresi Berganda

Teknik analisis data yang digunakan dalam penelitian ini adalah analisis regresi berganda (multiple regression analysis) dengan persamaan kuadrat terkecil atau ordinary least square (OLS). Inti dari metode ini adalah mengestimasi suatu garis regresi dengan jalan meminimalkan jumlah dari kuadrat kesalahan setiap observasi terhadap garis tersebut. Rumus yang digunakan adalah: (Sugiyono, 2008) 


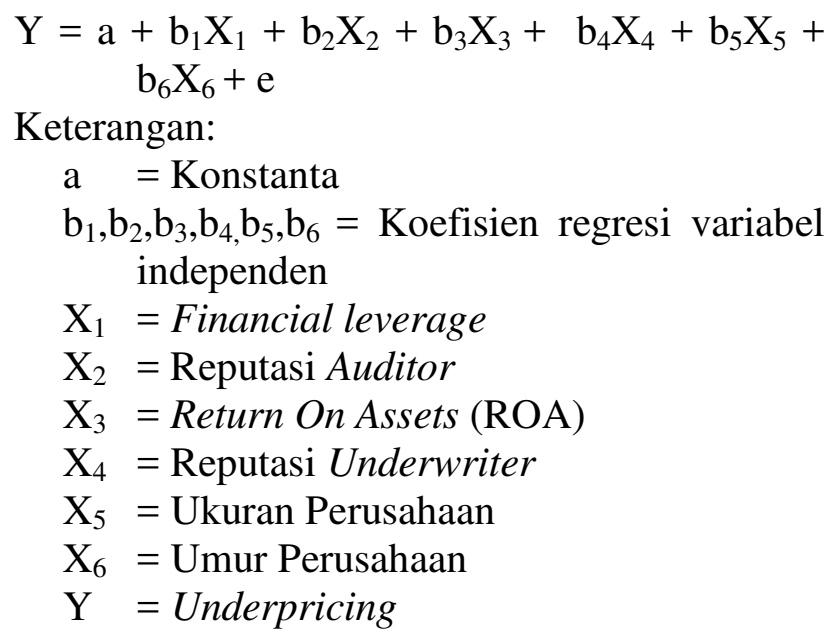
kesalahan).

2. Uji Normalitas

Uji normalitas bertujuan untuk menguji apakah dalam model regresi, variabel independen atau residualnya memiliki distribusi normal. Uji normalitas dilakukan karena uji statistik $\mathrm{t}$ dan uji statistik $F$ mengasumsikan bahwa nilai residual mengikuti distribusi normal. Kalau asumsi ini dilanggar maka uji statistik menjadi tidak valid untuk jumlah sampel yang kecil.

\section{Uji Asumsi Klasik}

Pengujian asumsi klasik bertujuan untuk mengetahui dan menguji kelayakan atas model untuk regresi yang digunakan dalam penelitian ini.

a. Uji Multikolinearitas

Mendeteksi ada tidaknya multikolinearitas dapat dilihat pada korelasi antar dua variabel independen. Jika antar variabel independen ada korelasi yang cukup tinggi (umumnya 0,90), maka hal ini merupakan indikasi adanya multikolinearitas

b. Uji Heterokedastisitas

uji heteroskedastisitas bertujuan untuk menguji apakah dalam sebuah model regresi, terjadi ketidaksamaan variance dari residual dari suatu pengamatan ke pengamatan lain. Jika variance dari residual satu pengamatan ke pengamatan lain tetap, maka disebut homoskedastisitas dan jika berbeda disebut heteroskedastisistas

c. Uji Autokorelasi

Bertujuan untuk menguji apakah dalam model regresi linier ada korelasi antara kesalahan pengganggu pada periode $t$ dengan kesalahan pengganggu pada periode $\mathrm{t}-1$ (sebelumnya) (Ghozali, 2006: 95). Jika terdapat korelasi, maka dapat dikatakan terjadi masalah otokorelasi

\section{TEKNIK PENGUJIAN HIPOTESIS}

i. Uji Statistik t

Prosedur pengujian hipotesis dengan menggunakan uji $\mathrm{t}$ (pengujian regresi secara parsial), dengan tujuan mengetahui apakan ada pengaruh yang nyata secara oarsial anatra variable terkait (Y) dengan variable bebas (X)

ii. Uji Statistik F

Uji $F$ dilakukan untuk mengetahui apakah variabel-variabel independen secara bersama-sama berpengaruh simultan terhadap variabel dependennya. Dasar pengambilan keputusan yang digunakan adalah probabilitas perbandingan dengan nilai alpha 1 . H0 ditolak apabila probabilitas (signifikan) alpha (0.05)

\section{HASIL DAN PEMBAHASAN}

1. Deskripsi Data

Penelitian ini dimaksudkan untuk mengetahui faktor-faktor yang memengaruhi tingkat underpricing perusahaan yang go public di Bursa Efek Indonesia periode tahun 2008-2012. Selama tahun tersebut terdapat 94 perusahaan yang melakukan IPO di BEI, 7 perusahaan dikeluarkan karena datanya tidak lengkap, 7 perusahaan mengalami overpricing, 15 perusahaan Initial Return (IR)nya nol (0), dan 5 perusahaan yang dikeluarkan karena range data terlalu jauh. Dengan demikian sampel yang digunakan dalam penelitian ini adalah 60 perusahaan.

2. Hasil Penelitian

a. Uji Normalitas 
penelitian ini menggunakan uji Kolmogorof Smirnov (uji K-S), apabila nilai sig (2-tailed) residual lebih besar dari $5 \%$, maka data tersebut berdistribusi normal. Hasil uji normalitas dapat dilihat pada tabel berikut:

\begin{tabular}{|ll|r|}
\hline & & $\begin{array}{c}\text { Unstandardized } \\
\text { Residual }\end{array}$ \\
\hline $\mathrm{N}$ & Mean & 60 \\
Normal Parameters ${ }^{\mathrm{a}}$ & Std. & 0,0000000 \\
& Deviation & 24,60660712 \\
& Absolute & 0,102 \\
Most Extreme Differences & Positive & 0,102 \\
& Negative & $-0,0.68$ \\
& & 0,808 \\
Kolmogorov-Smirnov $Z$ & 0,531 \\
Asymp. Sig. (2-tailed) & & \\
\hline
\end{tabular}

Berdasarkan tabel di atas nilai signifikansi residual sebesar 0,531 nilai ini lebih besar dari 0,05 sehingga dapat disimpulkan bahwa data telah terdistribusi normal.

\begin{tabular}{|c|c|c|}
\hline Variabel & $\begin{array}{c}\text { Durbin } \\
\text { Watson }\end{array}$ & $\begin{array}{c}\text { Kesimpula } \\
\mathrm{n}\end{array}$ \\
\hline $\mathrm{X}_{1}, \mathrm{X}_{2}, \mathrm{X}_{3}, \mathrm{X}_{4}$, & 1.810 & Tidak \\
$\mathrm{X}_{5}, \mathrm{X}_{6}$ & & terjadi \\
& & Autokorela \\
& & si \\
\hline
\end{tabular}

Normal P-P Plot of Regression Standardized Residual

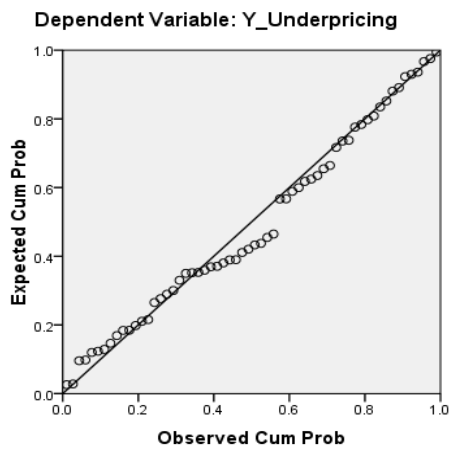

b. Uji Multikolinearitas
Hasil uji multikolinearitas dapat dilihat dari nilai VIF dan nilai tolerance, suatu model regresi terdeteksi adanya multikolinearitas jika nilai VIF $>10$ dan nilai tolerance $<0,1$.

\begin{tabular}{|l|c|c|l|}
\hline Variabel & Tolerance & VIF & Keterangan \\
\hline $\begin{array}{l}\text { Financial } \\
\text { Leverage } \\
\text { (FL) }\end{array}$ & .897 & 1,115 & $\begin{array}{l}\text { Tidak } \\
\text { terjadi } \\
\text { multikoline } \\
\text { aritas }\end{array}$ \\
\hline $\begin{array}{l}\text { Reputasi } \\
\text { Auditor } \\
\text { (RA) }\end{array}$ & .560 & 1,784 & $\begin{array}{l}\text { Tidak } \\
\text { terjadi } \\
\text { multikoline } \\
\text { aritas }\end{array}$ \\
\hline $\begin{array}{l}\text { Return On } \\
\text { Assets }\end{array}$ & 0,618 & 1,617 & $\begin{array}{l}\text { Tidak } \\
\text { terjadi } \\
\text { multikoline } \\
\text { aritas }\end{array}$ \\
\hline $\begin{array}{l}\text { Reputasi } \\
\text { Underwriter } \\
\text { (RU) }\end{array}$ & .794 & 1,259 & $\begin{array}{l}\text { Tidak } \\
\text { terjadi } \\
\text { multikoline } \\
\text { aritas }\end{array}$ \\
\hline $\begin{array}{l}\text { Size } \\
\text { Perusahaan }\end{array}$ & .724 & 1.382 & $\begin{array}{l}\text { Tidak } \\
\text { terjadi } \\
\text { multikoline } \\
\text { aritas }\end{array}$ \\
\hline $\begin{array}{l}\text { Tidak } \\
\text { terjadi } \\
\text { multikoline } \\
\text { aritas }\end{array}$ \\
\hline
\end{tabular}

Dari tabel di atas diperoleh nilai VIF < 10, dan nilai tolerance $>0,1$ hal ini menunjukkan bahwa semua variabel dalam penelitian ini tidak mengalami multikolinearitas. Dengan demikian dapat disimpulkan bahwa variabelvariabel yang digunakan dalam model regresi tidak mengandung multikolinieritas dan layak digunakan untuk analisis lebih lanjut.

$$
\text { c. Uji Autokorelasi }
$$

bertujuan untuk menguji apakah dalam model regresi linear ada korelasi antara residual pada periode $\mathrm{t}$ dengan residual pada periode $\mathrm{t}$ 1(sebelumnya)(Ghozali, 2009:95). Model regresi yang baik adalah regresi yang bebas dari autokorelasi. Hasil pengujian dapat dilihat pada tabel berikut ini:

Dari tabel di atas diperoleh nilai Durbin Watson berada di antara 1,55 sampai dengan 2,46 sehingga dapat disimpulkan

bahwa tidak terjadi gejala autokorelasi 
d. Uji Heteroskedasitas

bertujuan untuk menguji apakah dalam model regresi terjadi ketidaksamaan varian dari residual satu pengamatan ke pengamatan yang lain. Jika varian dari residual satu pengamatan ke pengamatan yang lain tetap, maka disebut homoskedastisitas, dan jika berbeda disebut heteroskedastisitas. Untuk mendeteksi ada atau tidaknya gejala heteroskedastisitas dapat dilakukan dengan Uji Glejser. Hasil pengujian dapat dilihat pada tabel berikut:

Tabel. 8

Hasil Uji Glejser

\begin{tabular}{|c|c|c|c|c|}
\hline Variabel & Koefisien & $\mathrm{T}_{\text {hitung }}$ & Sig. & Keterangan \\
\hline FL & .125 & .955 & .344 & homoskedastisitas \\
\hline RU & -.110 & -.667 & .508 & homoskedastisitas \\
\hline ROA & .201 & 1.277 & .207 & homoskedastisitas \\
\hline RA & -.137 & -987 & .328 & homoskedastisitas \\
\hline Size & -.220 & -1.432 & .158 & homoskedastisitas \\
\hline $\begin{array}{c}\text { Umur } \\
\text { Perusahaan } \\
\text { (UP) }\end{array}$ & -.141 & -970 & .336 & homoskedastisitas \\
\hline
\end{tabular}

Dari tabel di atas keenam variabel independen tidak signifikan karena nilai signifikansinya lebih besar dari 0,05 sehingga model tersebut tidak terjadi gejala heteroskedastisitas

3. Regresi Linier Berganda

Uji parsial digunakan untuk menguji pengaruh masing-masing variabel independen terhadap variabel dependen. Untuk mengetahui pengaruh Financial Leverage (FL), Reputasi Auditor (RA), Return On Assets, Reputasi Underwriter (RU), size, dan Umur Perusahaan (UP) terhadap underpricing digunakan koefisien regresi dengan t-hitung. Jika probabilitas kesalahan t-hitung lebih kecil dari tingkat signifikansi tertentu (5\%), maka variabel bebas mempunyai pengaruh yang signifikan terhadap variabel terikat dan Ha diterima. Hasil perhitungan uji $t$ dapat dilihat pada tabel berikut:

\begin{tabular}{|l|c|c|c|c|}
\hline Variabel & Koef & $\mathrm{T}_{\text {hitung }}$ & Sig. & Keterangan \\
\hline (Constant) & 202.574 & 3.335 & .002 & Tidak Signifikan \\
\hline FL & -0.77 & -115 & .909 & Tidak Signifikan \\
\hline RA & .129 & 2.271 & .027 & Signifikan \\
\hline ROA & -42.457 & -.465 & .644 & Tidak Signifikan \\
\hline RU & .108 & 1.549 & .127 & Tidak Signifikan \\
\hline Size & -6.236 & -2.853 & .006 & Signifikan \\
\hline $\begin{array}{l}\text { Umur } \\
\text { ersahaan }\end{array}$ & -19.449 & -2.783 & .007 & Signifikan \\
\hline
\end{tabular}

Financial Leverage (FL) mempunyai pengaruh negatif tetapi tidak signifikan terhadap underpricing pada perusahaan yang go public di Bursa Efek Indonesia. Hal ini ditunjukkan dengan nilai koefisien regresi sebesar $(-0,077)$ dan nilai t-hitung sebesar $(-0,115)$ dengan probabilitas tingkat kesalahan sebesar 90,9\%, nilai tersebut lebih besar dari tingkat signifikansi yang diharapkan $(90,9 \%>5 \%)$.

口 Reputasi Auditor (RA) mempunyai pengaruh positif dan signifikan terhadap underpricing pada perusahaan yang go public di Bursa Efek Indonesia. Hal ini ditunjukkan dengan nilai koefisien regresi sebesar 0,129 dan nilai t-hitung sebesar 2,271 dengan probabilitas tingkat kesalahan sebesar $2,7 \%$, nilai tersebut lebih kecil dari tingkat signifikansi yang diharapkan $(2,7 \%<$ $5 \%$ ).

- Return On Assets mempunyai pengaruh negatif tetapi tidak signifikan terhadap underpricing pada perusahaan yang go public di Bursa Efek Indonesia. Hal ini ditunjukkan dengan nilai koefisien regresi sebesar $(-42,457)$, nilai t-hitung sebesar $(-0,465)$ dengan probabilitas tingkat kesalahan sebesar $64,4 \%$ nilai tersebut lebih besar dari tingkat signifikansi yang diharapkan $(64,4 \%>$ $5 \%$ ).

Deputasi Underwriter (RU) mempunyai pengaruh positif tetapi tidak signifikan terhadap underpricing pada perusahaan yang go public di Bursa Efek Indonesia. Hal ini ditunjukkan dengan nilai koefisien regresi sebesar 0,108 nilai thitung sebesar 1,549 dengan probabilitas 
tingkat kesalahan sebesar $12,7 \%$ nilai tersebut lebih besar dari tingkat signifikansi yang diharapkan $(12,7 \%>$ $5 \%)$.

Size mempunyai pengaruh negatif dan signifikan terhadap underpricing pada perusahaan yang go public di Bursa Efek Indonesia. Hal ini ditunjukkan dengan nilai koefisien regresi sebesar $(-6,236)$, nilai t-hitung sebesar $(-2,853)$ dengan probabilitas tingkat kesalahan sebesar $0,6 \%$ nilai tersebut lebih kecil dari tingkat signifikansi yang diharapkan $(0,6 \%<5 \%)$.

Umur Perusahaan (UP) mempunyai pengaruh negatif dan signifikan terhadap underpricing pada perusahaan yang go public di Bursa Efek Indonesia. Hal ini ditunjukkan dengan nilai koefisien regresi sebesar $(-19,499)$, nilai t-hitung sebesar $(-2,783)$ dengan probabilitas tingkat kesalahan sebesar $0,7 \%$ nilai tersebut lebih kecil dari tingkat signifikansi yang diharapkan $(0,7 \%<$ $5 \%)$.

\section{KESIMPULAN}

Financial Leverage ( $F L)$, RA, ROA, $\mathrm{RU}$, size, dan Umur Perusahaan (UP) berpengaruh signifikan terhadap underpricing. Hal ini ditunjukkan dengan nilai F-hitung sebesar 2,548 dengan probabilitas tingkat kesalahan sebesar 3\% nilai tersebut lebih kecil dari tingkat signifikansi yang diharapkan $(3 \%<$ $5 \%)$.

口 Nilai Koefisien Determinasi $\left(R^{2}\right)$ sebesar 0,214 yang berarti bahwa hanya $21,4 \%$ perubahan tingkat underpricing yang dapat dijelaskan oleh ketiga variabel bebas, sedangkan sisanya sebesar $78,6 \%$ dijelaskan oleh faktor lain di luar penelitian.

- Implikasi dari hasil penelitian ini yaitu semakin besar koefisien determinasi $\mathrm{R}^{2}$, berarti semakin baik model regresi tersebut karena variabel independen dapat menjelaskan variabel dependen secara lebih baik.

\section{DAFTAR PUSTAKA DAFTAR PUSTAKA}

Abdullah, Syukriy. 2002.'Faktor-faktor yang Mempengaruhi Underpricing dan Kinerja Jangka Panjang." Kajian Ekonomi dan Bisnis.Vol.7.Hlm 13-23.

Darmadji, T dan Fakhrudin M.H. 2002. Pasar Modal di Indonesia Pendekatan Tanya Jawab. Jakarta: Salemba Empat

Darmadji, Tjiptono dan Hendy M. 2008. Pasar Modal di Indonesia Pendekatan Tanya Jawab. Jakarta:Salemba Empat.

Ernyan dan Suad Husnan. 2003. Perbandingan Underpricing Penerbitan Saham Perdana Perusahaan Keuangan dan Non-Keuangan di Pasar Modal Indonesia: Pengujian Hipotesis Asimetri Informasi. Jurnal Ekonomi dan Bisnis Indonesia Vol.17, No.4, 372-383. FE-UGM

Ghozali, Imam. 2006. Aplikasi Analisis Multivariat dengan Program SPSS. Semarang:Badan Penerbit Universitas Diponegoro.

Gumanti, Tatang Ary. 2003. "Underpricing dan Biaya-Biaya di Sekitar Initial Public Offering." Jurnal Akuntansi dan Keuangan.Vol 5.No.2. Hlm 135-147.

Indiati, Imma Agustika. 2009. "Pengaruh ROA, Reputasi Underwriter, Kondisi Pasar, Tingkat Diskonto SBI, dan Tingkat Inflasi terhadap Underpricing pada Penawaran Saham Perdana." Skripsi tidak diterbitkan. UNY.

Indonesian Capital Market Directory 20082012

Indrawati, Novita. 2006. "Analisis Faktor-faktor yang Mempengaruhi Underpricing pada Penawaran Umum Perdana." 


\section{JURNAL MANAJEMEN VOL 5 NO.1 JUNI 2015}

Jurnal Akuntansi dan Bisnis.Vol.5.Hlm $1-11$.

Jogiyanto.2008.Teori Portofolio dan Analisis Investasi.Yogyakarta:BPFE.

Nurhidayati dan Indriantoro. 1998. Analisis Faktor-Faktor Yang Berpengaruh Terhadap Tingkat Underpriced Pada Penawaran Saham Perdana di BEJ. Jurnal Ekonomi dan Bisnis Indonesia, Vol 13, No 1.

Prabaningrum, Mahendrawati. 2008. "Pengaruh Reputasi Underwriter, Firm Size dan Persentase Kepemilikan Saham Manajemen terhadap Underpricing pada saat IPO di BEJ." Skripsi tidak diterbitkan. UNY.

Rodoni, Ahmad. 2003. Penawaran Saham Perdana: Pengalaman di Bursa Efek Jakarta. Jurnal Ekonomi dan Bisnis Indonesia Vol.17, No.4, 398-419. Program Pasca Sarjana Universitas Sahid.

Sartono, R. Agus. 1996. Manajemen Keuangan Teori dan Aplikasi. Yogyakarta: BPFE

Setianingrum, Roskarina dan Tjilik Suwito. 2009. "Faktor-Faktor yang Mempengaruhi Tingkat Underpricing pada Perusahaan yang Go Public di BEJ.” Jurnal Fokus Manajerial.Vol.6,No.1.Hlm 84-95.

Sugiyono. 2008. Metode Penelitian Bisnis. Bandung:Alfabeta.

Sunariyah. 2005. Pengantar Pasar Modal. Yogyakarta: UPP AMP YKPN

Suyatmin dan Sujadi. 2007. Faktor-Faktor Yang Mempengaruhi Underpricing Pada Penawaran Umum Perdana Di Bursa Efek Jakarta. Jurnal manajemen dan Bisnis, Vol 10, No 1.
Triandaru, Sigit dan Totok B. 2008. Bank dan Lembaga Keuangan. Edisi Dua. Jakarta:Salemba Empat.

Trisnaningsih, Sri. 2006. "Analisis FaktorFaktor yang Mempengaruhi Tingkat Underpricing pada Perusahaan yang Go Public Di Bursa Efek Jakarta." Jurnal Akuntansi dan Keuangan.Vol 4.No 2. Hlm 195-208.

Trisnawati,Rina. 2000. Pengaruh Informasi Prospektus Pada Retrun Saham di Pasar Perdana. Simposium Nasional Akuntansi II, IAI,

Wirawanyasa, Gerianta. 2009. "Penyebab Underpricing pada Penawaran Saham Perdana di BEJ." Jurnal Akuntasi dan Bisnis.Vol 3.No 2. Hlm 1-29 Denpasar Bali.

Trisnaningsih, Sri. 2006. "Analisis Faktor-Faktor yang Mempengaruhi Tingkat Underpricing pada Perusahaan yang Go Public Di Bursa Efek Jakarta." Jurnal Akuntansi dan Keuangan.Vol 4.No 2. Hlm 195-208. 